\title{
In Vitro Antibacterial Activity of Two Mosses: \\ Calymperes Erosum C. Mull and Bryum coronatum \\ Schwaegr from South-Western Nigeria
}

\author{
Tedela P. O., Adebiyi, A. O., \& Aremu, A. \\ Department of Plant Science \\ Ekiti State University, P. M. B. 5363, Ado-Ekiti, Nigeria
}

David, O. M. (Corresponding author)

Department of Microbiology, Ekiti State University, P. M. B. 5363, Ado-Ekiti, Nigeria

E-mail: davidoluwole5@gmail.com

Received: February 9, 2014 Accepted: February 24, 2014

doi:10.5296/jbls.v5i2.5730 URL: http://dx.doi.org/10.5296/jbls.v5i2.5730

\begin{abstract}
Bryophytes are poikilohydric in nature and the oldest known land plant. Their striking resistance to microbial attack suggests their inherent production of antibacterial compounds. The antibacterial activity of acetone, ethanol, methanol and hexane extracts of Calymperes erosum C. Mull and Bryum coronatum Schwaegr were investigated against twenty clinically important bacteria pathogens. Agar dilution method was used to assess the effectiveness of the extracts on the test organisms. The minimum inhibitory concentrations of the extracts of $C$. erosum were between $<0.625$ and $>5.0 \mathrm{mg} / \mathrm{ml}$. Klebsiella pneumoniae ATCC 10031, Enterococcus feacalis ATCC 29212, Bacillus pumilis ATCC 14884 and Enterobacter cloaca ATCC 13047 in decreasing order are most sensitive to the extracts while Proteus vulgaris KZN, Staphylococcus aureus OK2 and Shigella sonnei ATCC 29930 were resistant to the extracts. Ethanolic extract was the most effective among the extracts followed by acetone extract. $B$. coronatum had relatively lower activity. While the mosses screened proved to be promising sources of antimicrobial and biologically active compounds, their toxicity and action mechanism still needed to be investigated.
\end{abstract}

Keyword: Calymperes erosum, Bryum coronatum, Mosses, Antibacterial, Pathogen, bryophytes 


\section{Introduction}

Bryophytes represent the second largest group of land green plants after angiosperms and are taxonomically placed between algae and pteridophytes (Asakawa, 2007). The bryophytes group consist of three subgroups: Bryophyta (mosses), Marchantiophyta (liverworts) and Anthocerotophyta (hornworts) (Campbell and Reece, 2002). It is estimated that there are between about 15000 and 25000 bryophyte species known in the world (Goffinet and Shaw, 2009).

Bryophytes have long been considered to be insignificant in the economy of man except for those used in packing, plugging and decoration. However, Saxena and Harrinder (2004) reported that the ecological role of bryophytes in any ecosystem is significant. In China where herbal medicine is extensively and widely accepted, bryophytes have been used as "crude drugs". Many medicinal bryophytes have been recognized (Madson and Pates, 1952; Wu, 1977; Ding, 1982; Ando, 1983). In particular, the occurrence of antibiotic substances in bryophytes has been documented by scientists (Dulger, 2005; Bodade et al, 2008; Russell, 2010; Elibol et al, 2011; Savaroglu et al, 2011). Although bryophytes normally grow in humid habitats, they are relatively free from microbial attacks and this scarcity of disease indicates that bryophytes are able to elaborate constitutive or inducible small - molecule antimicrobials. In fact, bryophytes have been proven to be a rich source of antibiotics and attempts to find potent, nontoxic broad spectrum antibiotics from the sources have been widely undertaken (Xie and Lou, 2009). However, reports of ethnobotanical researches into this plant group are minimal (Zhu et $a l$, 2006). The reasons for this are the difficulty that researchers have with their identification, the limited amount of the same species available for analyses due to their inconspicuous position in the ecosystem and the difficulty with which analysis can be conducted since it relies on sophisticated methods (Savaroglu, 2011). Though, few studies have successfully investigated the chemistry of bryophytes (Asakawa, 2001; Jockovic et al, 2008), it is generally known that bryophytes possess extremely high amounts of terpenoids, phenolics (flavonoids and bibenzyl derivatives), glycosides, fatty acids as well as some rare aromatic compounds (Jockovic et al, 2008; Sabovljevic et al, 2008).

Recently, the public demand for herbal medicine and the rise of antibiotic-resistant bacteria have motivated scientists to look for new natural sources with potential pharmaceutical capabilities (Cowan, 1999). Zhu et al (2006) suggested that bryophytes are one of the most significant and promising sources of antibiotics and biologically active compounds in nature.

This study analysed the antimicrobial activities of different extracts of Calymperes erosum $\mathrm{C}$. Mull and Bryum coronatum Schwaegr against some bacterial species.

\section{Materials and methods}

\subsection{Plant Materials}

Plant materials were collected in March 2012 in growing areas in Ekiti State University, Ado-Ekiti. The species was authenticated at the Herbarium section of the Department of Plant Science, Ekiti State University, Ado-Ekiti, Nigeria. Voucher specimens were prepared and deposited in the Herbarium of the University for reference. Plant samples were air dried for 
four days and pulverized. Powdered plant material (40 g each) was separately extracted in acetone, ethanol and methanol for $48 \mathrm{~h}$ with periodic manual shaking after which the extracts were filtered through Whatman No. 1 filter paper. The extracts were evaporated to dryness under reduced pressure at $40^{\circ} \mathrm{C}$ using a rotary evaporator (Laborota 4000 -efficient, Heldolph, Germany). Individual crude extracts was diluted using 5\% dimethylsulphoxide to give 50 $\mathrm{mg} / \mathrm{mL}$ stock solution (Taylor et al., 1995). This was then diluted to the required concentrations for the bioassay.

\subsection{Test Organisms}

Twenty bacterial strains used in this study were obtained from the Department of Microbiology, Ekiti State University, Ado-Ekiti, Nigeria. Eight Gram positive were used, the isolates include: Bacillus cereus ATCC 10702, Bacillus pumilis ATCC 14884, Bacillus subtilis KZN, Enterococcus feacalis ATCC 29212, Micrococcus luteus, Staphylococcus aureus ATCC 6538, Staphylococcus aureus OK1 and Staphylococcus aureus OK2. The Gram negative organisms used include: Acinetobacter calcoaceticus CSIR, Escherichia coli ATCC 25932, Escherichia coli ATCC 8739, Enterobacter cloaca ATCC 13047, Klebsiella pneumoniae ATCC 10031, Klebsiella pneumoniae KZN Pseudomonas aeruginosa ATCC 19582, Proteus vulgaris KZN, Proteus vulgaris ATCC 6830, Proteus vulgaris CSIR 0030, Serratia mercesscens ATCC 9986 and Shigella sonnei ATCC 29930. Each strain was maintained on Nutrient Agar (Oxoid) plates. The grown cultures were used for preparation of bacterial suspensions in sterile distilled water with densities adjusted to 0.5 McFarland Standard.

\subsection{Antibacterial Activity Assay}

Antibacterial activity was determined by the methods of Afolayan and Meyer (1997) using Mueller-Hinton agar (Oxoid). Briefly, different concentrations of the extracts were prepared in 5\% Dimethyl Sulfoxide (DMSO) while diluent (5\% DMSO) was used as control. Molten medium containing the extracts at final concentrations of $0.625,1.25,2.50$ and $5.00 \mathrm{mg} / \mathrm{ml}$ were poured into Petri dishes, swirled gently until the agar began to set, and left over night for solvent to evaporate completely. Agar plates containing $1 \%$ of the extracting solvents were used as controls. The test organisms were streaked in radial pattern on the agar plates, incubated under aerobic conditions at $37{ }^{\circ} \mathrm{C}$ and examined after $24 \mathrm{~h}$. Each treatment was performed in triplicate and complete suppression of growth at a specific concentration of an extract was required for it to be declared active (Sindambiwe et al., 1999; Mathekga et al., 2000). The lowest concentration that inhibits the growth of the organisms was recorded and considered as the minimum inhibitory concentration (MIC) value.

Table 1. Minimum inhibitory concentrations (MICs) of extracts of C. erosum

\begin{tabular}{|c|l|c|c|c|c|}
\hline \multirow{2}{*}{ Gram Reaction } & \multicolumn{2}{|c|}{ Isolates } & \multicolumn{4}{c|}{ Extractants } \\
\cline { 3 - 6 } & & Acetone & Ethanol & Methanol & Hexane \\
\hline \multirow{3}{*}{ Positive } & B. cereus ATCC 10702 & 2.50 & $<0.625$ & 1.25 & $>5.0$ \\
\cline { 2 - 6 } & B. pumilis ATCC 14884 & 2.50 & $<0.625$ & 2.50 & $<0.625$ \\
\cline { 2 - 6 } & B. subtilis KZN & 0.625 & $>5.0$ & 5.00 & $>5.0$ \\
\hline
\end{tabular}




\begin{tabular}{|l|l|c|c|c|c|}
\hline \multirow{7}{*}{} & Enter. feacalis ATCC 29212 & 2.50 & $<0.625$ & 1.25 & 0.625 \\
\cline { 2 - 6 } & M. luteus & 2.50 & 5.00 & 5.00 & 2.50 \\
\cline { 2 - 6 } & St. aureus ATCC 6538 & 2.50 & $<0.625$ & $>5.0$ & 2.50 \\
\cline { 2 - 6 } & St. aureus OK1 & $>5.0$ & 1.25 & 5.00 & 5.00 \\
\cline { 2 - 6 } & St. aureus OK2 & 2.50 & 5.00 & $>5.0$ & 5.00 \\
\hline A. calcoaceticus CSIR & 0.625 & 1.25 & $<0.625$ & 2.50 \\
\cline { 2 - 6 } & E. coli ATCC 25932 & 2.50 & $<0.625$ & $>5.0$ & 2.50 \\
\cline { 2 - 6 } & E. coli ATCC 8739 & 1.25 & $<0.625$ & $>5.0$ & 2.50 \\
\cline { 2 - 6 } & Ent. cloaca ATCC 13047 & 1.25 & $<0.625$ & 2.50 & 5.00 \\
\cline { 2 - 6 } & K. pneumonia ATCC 10031 & 1.25 & $<0.625$ & 0.625 & $<0.625$ \\
\cline { 2 - 6 } & K. pneumonia KZN & 2.50 & 1.25 & $>5.0$ & $<0.625$ \\
\cline { 2 - 6 } & Ps. aeruginosa ATCC 19582 & 1.25 & $<0.625$ & 2.50 & $<0.625$ \\
\cline { 2 - 6 } & P. vulgaris KZN & $>5.0$ & 5.00 & 5.00 & 2.50 \\
\cline { 2 - 6 } & P. vulgaris ATCC 6830 & $<0.625$ & $<0.625$ & 5.00 & $>5.0$ \\
\cline { 2 - 6 } & P. vulgaris CSIR 0030 & 0.625 & 2.50 & $>5.0$ & 2.50 \\
\cline { 2 - 6 } & Se. mercescens ATCC 9986 & 2.50 & 1.25 & $>5.0$ & 5.00 \\
\cline { 2 - 5 } & Sh. sonnei ATCC 29930 & 5.00 & 5.00 & $>5.0$ & 2.50 \\
\hline
\end{tabular}

Table 2. Minimum inhibitory concentrations (MICs) of extracts of B. coronatum

\begin{tabular}{|l|l|c|c|c|c|}
\hline \multirow{2}{*}{ Gram Reaction } & \multicolumn{4}{|c|}{ Isolates } & \multicolumn{4}{c|}{ Extractants } \\
\cline { 3 - 6 } & & Acetone & Ethanol & Methanol & Hexane \\
\hline \multirow{5}{*}{ Positive } & B. cereus ATCC 10702 & $>5.00$ & $>5.00$ & 2.50 & 2.50 \\
\cline { 2 - 6 } & B. pumilis ATCC 14884 & 1.25 & $>5.00$ & 5.00 & $>5.00$ \\
\cline { 2 - 6 } & B. subtilis KZN & $>5.00$ & 5.00 & $>5.00$ & $>5.00$ \\
\cline { 2 - 6 } & Enter. feacalis ATCC 29212 & $>5.00$ & $>5.00$ & 0.625 & $>5.00$ \\
\cline { 2 - 6 } & M. luteus & 5.00 & $>5.00$ & $>5.00$ & $>5.00$ \\
\cline { 2 - 6 } & St. aureus ATCC 6538 & $>5.00$ & $>5.00$ & $>5.00$ & $>5.00$ \\
\cline { 2 - 6 } & S. aureus OK1 & $>5.00$ & 2.50 & 2.50 & 0.625 \\
\cline { 2 - 6 } & S. aureus OK2 & 5.00 & 5.00 & $>5.00$ & $>5.00$ \\
\hline \multirow{5}{*}{ Negative } & A. calcoaceticus CSIR & 0.625 & 0.625 & 1.25 & 5.00 \\
\cline { 2 - 6 } & E. coli ATCC 25932 & $>5.00$ & $>5.00$ & $>5.00$ & $>5.00$ \\
\cline { 2 - 6 } & E. coli ATCC 8739 & $>5.00$ & 0.625 & 2.50 & $>5.00$ \\
\cline { 2 - 6 } & Ent. cloaca ATCC 13047 & $>5.00$ & $>5.00$ & $>5.00$ & 0.625 \\
\cline { 2 - 6 } & K. pneumonia ATCC 10031 & $>5.00$ & 5.00 & $>5.00$ & $>5.00$ \\
\cline { 2 - 6 } & K. pneumonia KZN & $>5.00$ & $>5.00$ & $>5.00$ & $>5.00$ \\
\cline { 2 - 6 } & Ps. aeruginosa ATCC 19582 & 1.25 & $>5.00$ & 5.00 & 0.625 \\
\cline { 2 - 6 } & P. vulgaris KZN & 0.625 & 0.625 & $>5.00$ & 0.625 \\
\cline { 2 - 6 } & P. vulgaris ATCC 6830 & $>5.00$ & $>5.00$ & $>5.00$ & $>5.00$ \\
\cline { 2 - 6 } & P. vulgaris CSIR 0030 & $>5.00$ & $>5.00$ & 0.625 & $>5.00$ \\
\cline { 2 - 6 } & Se. mercesscens ATCC 9986 & 2.50 & $>5.00$ & 0.625 & $>5.00$ \\
\cline { 2 - 6 } & Sh. sonnei ATCC 29930 & 2.50 & $>5.00$ & 5.00 & 1.25 \\
\hline
\end{tabular}




\section{Results and Discussion}

The emerging resistant bacteria pathogens proved to be serious threat to human health globally (Sanchez and Kouznetsov, 2010; Lopez-Pueyo et al., 2011). Treatment with orthodox medicine is ineffective in most cases due to different resistant mechanisms hence the need for cheap, effective and natural medicinal compounds (Basile et al., 1998; Saboljevic et al., 2006). Nearly all bryophytes are known to resist fungi and bacteria attack. They are also not consumed by molluscs, insects and mammals (Basile et al., 1998; Asakawa, 2001). Compared to vascular plants, the use of bryophytes as antibacterial agent is scanty despite their worldwide occurrence. The antibacterial properties of acetone, ethanol, methanol and hexane extracts of $C$. erosum and $B$. coronatum were screened against twenty medically important bacteria. The extracts showed varying degrees of inhibitory effects on the test organisms with the control (5\% DMSO) has no inhibition on the organisms. Most of the active substances in medicinal plants are in aromatic or saturated organic nature. Some of the substances are reported to be easily extracted by polar and non-polar solvents (Cowan, 1999; Altuner et al., 2011). The MICs ranges were outside the test concentrations. They were between $<0.625$ and $>5.0 \mathrm{mg} / \mathrm{ml}$. Klebsiella pneumoniae ATCC 10031, Enter. feacalis ATCC 29212, B. pumilis ATCC 14884 and Ent. cloaca ATCC 13047 in decreasing are most sensitive to the extracts of $C$. erosum while $P$. vulgaris KZN, S. aureus OK2 and S. sonnei ATCC 29930 were resistant to the extracts. Mosses are a rich source of secondary metabolites with antimicrobial activity (Asakawa, 1981, Sabovljevic et al., 2006; Asakawa, 2007; Mellegard et al., 2009). Different antimicrobial agents have been isolated from the bryophytes and they are used for the treatment of infectious diseases (Dulger et al., 2005; Singt et al., 2006; Dulger et al., 2009; Bukvieki et al., 2012). Ethanolic extract was the most effective among the extracts followed by acetone extract. Ethanol and acetone invariably extract the active compound from the plant at a rate or amount higher than the other extractants. According to Nikolajeva et al. (2012), ethanolic extract has the best activity against pathogenic bacteria. They reported that extracts of seven out of 11 bryophytes were effective in curtailing the growth of Staphylococcus aureus. Khanam et al. (2011) reported ethanolic extracts of Marchantia palmata to have high antibacterial activity. However, Mukhopadhyay et al. (2013) reported low activity of ethanolic extracts of some bryophytes. Methanolic extract had the least effectiveness among the extracts. The extract of non-polar solvent (hexane) had low activity against the isolates though its activity is relatively better than methanol as shown in Table 1. The activity of the extracts of B. coronatum was very poor compared to the $C$. erosum. The activity of $B$. coronatum was pronounced against $A$. calcoaceticus CSIR, P. vulgaris KZN and $S$. aureus OK1. The action of the extracts may be due to their actions on the cell wall or any other parts of the test organisms as suggested by Olofin $e t$ al. (2013). Acetone extract was very active against $A$. calcoaceticus CSIR and $P$. vulgaris KZN while the hexane extract was active against $S$. aureus OK1 (Table 2). Relatively, Gram negative bacteria were more resistant / susceptible to the extracts of $C$. erosum while the extracts of $B$. coronatum of had low inhibitory activity on both Gram positive and negative bacteria. The activity of the mosses on the test organisms may be due to the presence of the secondary metabolites present in the mosses (Singh et al., 2007; Chaudhary and Kumar, 2011). The results of the preliminary screening the both organic and inorganic extracts of two bryophytes tested against the test organisms showed different biological activity considering the 
extraction solvents. The active nature and the mechanism of action(s) of the active compounds in the two plants are open to further investigations.

\section{References}

Afolayan, A. J., \& Meyer, J. M. (1997). The antimicrobial activity of 3, 5, 7-trihydroxyflavone isolated from the shoots of Helichrysum aureonitens. J. Ethnopharmacol. 57, 177-181. http://dx.doi.org/10.1016/S0378-8741(97)00065-2

Altuner, E. M., Ceter, T. P., Bayar, E. N., Aydin, S. N., Arici, F. R., Suleymanolu G. Z., \& Edis, E. (2011). Investigation on antimicrobial effects of some moss species collected from Kastamonu Region. Commun. Fac. Sci. Univ. Ank. 23(1-2), 33-43.

Asakawa, Y. (1981). Biologically active substances obtained from bryophytes. The J. Hattori Botanic. Lab..50, 123-142.

Asakawa, Y. (2001). Recent advances in phytochemistry of bryophytes acetogenins, terpenoids and bis(bibenzyl)s from selected Japanese, Taiwanese, New Zealand, Argentinean and $\begin{array}{llll}\text { European } & \text { liverworts. } & \text { Phytochem. } & \text { 297-312. }\end{array}$ http://dx.doi.org/10.1016/S0031-9422(00)00454-4

Asakawa, Y. (2007). Biologically active compounds from bryophytes. Pure and Appl. Chem. 79(4), 557-580. http://dx.doi.org/10.1351/pac200779040557

Basile, A., Sorbo, S., Giordano, S., Lavitola, A. \& Castaldo, C. R. (1998). Antibacterial activity in Pleurochaete squarrosa extract (Bryophyta). Inter. J. Antimicrob. Agents. 10, 169-172. http://dx.doi.org/10.1016/S0924-8579(98)00028-4

Bodade, R. G., Borkar, P. S., Saiful, A. M., \& Khobragade, C. N. (2008). In vitro screening of Bryophytes for antimicrobial activity. J. Med. Plants Res. 7(4), 23-28.

Bukvieki, D., Veljic, M., Sokovic, M., Grujic, S., \& Marin, P. D. (2012). Antimicrobial activity of methanol extracts of Abietinella abietina, Neckera crispa, Platyhypnidium riparoides, Cratoneuron filicinum and Campylium protensum mosses. Arch. Biol. Sci., Belgrade. 64(3), 911-916.

Campbell, N. A., \& Reece, J. B. (2002). Biology, $6^{\text {th }}$ edition, Pearson Education, Inc., San Francisco, CA

Chaudhary, B. L., \& Kumar, P. (2011). Antibacterial activity and preliminary phytochemical screening of epiphytic moss Stereophyllum ligulatum Jaeg. Intern. J. Pharma. Bio. Sci. 2(4), 674-681.

Cowan, M. M. (1999). Plant products as antimicrobial agents. Clin. Microbiol. Rev.12(4), 564-582.

Da Silva, C. M., Mota, F. B. C., Rodrigues, M. D., Alves, O. D., \& Maia, V. H. (2013). Crude extracts and semi-fractions from Myracrodruon urundeuva with antibacterial activity against American Type Culture Collection (ATCC) strains of clinical relevance. J. Med. Plants Res. 7(32), 2407-2413. http://dx.doi.org/10.5897/JMPR12.1264 
Dulger, B., Hacioglu, N., \& Uyar, G. (2009). Evaluation of antimicrobial activity of some mosses from Turkey. Asian J. Chem. 21, 4093-4096.

Dulger, B., Yayintas, O. T., \& A. Gonuz (2005). Antimicrobial activity of some mosses from Turkey. Fitoterapia. 76, 730-732. http://dx.doi.org/10.1016/j.fitote.2005.07.006

Elibol B, Ezer T, Kara R, Yuvali C., \& Colak E (2011). Antifungal and antibacterial effects of some acrocarpic mosses. Afr. J. Biotechnol., 10(6), 986-989.

Goffinet B \& Shaw AJ (2009). Bryophyte Biology. Cambridge University Press, Cambridge, UK, p.565.

Jockovic, N., Andrade, P. B., Valentao, P., \& Sabovljevic, M. (2008). HPLC-DAD of phenolics in bryophytes Lunularia cruciate, Brachytheciastrum velutinum and Kindbergia praelonga. J. Serb. Chem. Soc. 73, 1161-1167. http://dx.doi.org/10.2298/JSC0812161J

Khanam, R., Chaudhary, B. L. Khanam, S., \& Kumar, P. (2011). Antibacterial Activity of Marchantia palmata Nees, Asian J. Biochem Pharmaceut. Res. 1(2), 27-36.

Lopez-Pueyo, M. J., Barcenilla-Gaite, F., Amaya-Villar, R., \& Garnacho-Montero, J. (2011). Antibiotic multiresistance in critical care units. Med. Intensiva. 35:41-53.

Madsen, G. C., \& A. L. Pates. (1952). Occurrence of antimicrobial substances in chlorophyllose plants growing in Florida. Botanical Gazette. 113, 293-300. http://dx.doi.org/10.1086/335721

Mellegard, H., Stalheim, T., Hormazabel, V., Granum, P. E., \& Hardy, S. P. (2009). Antibacterial activity of sphagnum acid and other phenolic compounds found in Sphagnum papillasum against food-borne bacteria. Lett. Appl. Microbiol. 49, 85-90. http://dx.doi.org/10.1111/j.1472-765X.2009.02622.x

Mukhopadhyay S. T., Mitra S., Biswas A., Das N., \& Poddar-Sarkar, M. (2013). Screening of antimicrobial and antioxidative potential of selected Eastern Himalayan mosses. Eur. J. Med. Plants. 3(3), 422-428.

Nikolajeva, V., Liepina, L., Petrina, Z., Krumina, G., Grube, M., \& Muiznieks, I. (2012). Antibacterial activity of extracts from some bryophytes. Adv. Microbiol. 2, 345-353. http://dx.doi.org/10.4236/aim.2012.23042

Olofin, T. A., Akande, A. O., \& Oyetayo, V. O. (2013). Assessment of the antimicrobial properties of fractions obtained from bryophytes. J. Microbiol. Antimicrob. 5(5), 50-54. http://dx.doi.org/10.5897/JMA11.055

Russell MD (2010). Antibiotic activity of extracts from some Bryophytes in South Western British Columbia. Med. Std. J. Austr. 2, 9-14.

Saboljevic, A., Sokovic, M., Saboljevic, M., \& Grubisic, D. (2006). Antimicrobial activity of Bryum argenteum. Fitoterapia. 77, 144-145. http://dx.doi.org/10.1016/j.fitote.2005.11.002

Sanchez, J. G. B., \& Kouznetsov, V. V. (2010). Antimycobacterial susceptibility testing 


\section{Macrothink}

Journal of Biology and Life Science ISSN 2157-6076 2014, Vol. 5, No. 2

methods for natural products research. Braz. J. Microbiol. 41, 270-277. http://dx.doi.org/10.1590/S1517-83822010000200001

Savaroglu F, Filik IC, Oztopcu VP, Kabadere S, IIhan S, \& Uyar R (2011). Determination of antimicrobial and antiproliferative activities of the aquatic moss, Fontinalis antipyretica Hedw. Turk. J. Biol. 35, 361-369.

Saxena, K., \& Harinder, S. (2004). Uses of bryophytes. Reson., 9(6), 56-65. http://dx.doi.org/10.1007/BF02839221

Singh, M., Rawat, A. K. S., \& Govindarajan R. (2007), Antimicrobial activity of some Indian mosses, Fitoterapia. 78, 156-158. http://dx.doi.org/10.1016/j.fitote.2006.10.008

Wu, P.C. (1977). Rhodobryum giganteum (Schwaegr.) par. can be used for curing cardiovascular disease. Acta phytotax. SIN, 15, 93.

Xie, C. F., \& Lou, H. X. (2009). Secondary metabolities in bryophytes: An economical aspect. Chem. Biodiversity. 6, 303-312. http://dx.doi.org/10.1002/cbdv.200700450

Zhu, R.L., Wang D., Xu L., Shi R.P, Wang J., \& Zheng, M. (2006). Antibacterial activity in extracts of some bryophytes fron China and Mongolia. J. Bot. Lab. 100, 603-615.

\section{Copyright Disclaimer}

Copyright for this article is retained by the author(s), with first publication rights granted to the journal.

This is an open-access article distributed under the terms and conditions of the Creative Commons Attribution license (http://creativecommons.org/licenses/by/3.0/). 